\title{
Redness Variation in the Eurasian Scops-Owl Otus scops is Due to Pheomelanin But is Not Associated with Variation in the Melanocortin-1 Receptor Gene (MC1R)
}

Authors: Avilés, Jesús M., Cruz-Miralles, Ángel, Ducrest, Anne-Lyse, Simon, Céline, Roulin, Alexandre, et al.

Source: Ardeola, 67(1) : 3-13

Published By: Spanish Society of Ornithology

URL: https://doi.org/10.13157/arla.67.1.2020.ra1

BioOne Complete (complete.BioOne.org) is a full-text database of 200 subscribed and open-access titles in the biological, ecological, and environmental sciences published by nonprofit societies, associations, museums, institutions, and presses.

Your use of this PDF, the BioOne Complete website, and all posted and associated content indicates your acceptance of BioOne's Terms of Use, available at www.bioone.org/terms-of-use.

Usage of BioOne Complete content is strictly limited to personal, educational, and non - commercial use. Commercial inquiries or rights and permissions requests should be directed to the individual publisher as copyright holder. 


\title{
Research Papers
}

\section{REDNESS VARIATION IN THE EURASIAN SCOPS-OWL OTUS SCOPS IS DUE TO PHEOMELANIN BUT IS NOT ASSOCIATED WITH VARIATION IN THE MELANOCORTIN-1 RECEPTOR GENE $(M C 1 R)$}

\author{
LA VARIACIÓN EN EL GRADO DE ROJISMO EN EL \\ AUTILLO EUROPEO OTUS SCOPS ES DEBIDA A FEOMELANINAS \\ PERO NO SE ASOCIA CON VARIACIÓN EN EL GEN RECEPTOR \\ DE LA MELANOCORTINA 1
}

\begin{abstract}
Jesús M. Avilés ${ }^{1}{ }^{*}$, Ángel CruZ-Miralles ${ }^{2}$, Anne-Lyse DuCrest ${ }^{3}$, Céline SimoN ${ }^{3}$,
\end{abstract} Alexandre Roulin ${ }^{3}$, Kazumasa WAKAMATsu ${ }^{4}$ and Deseada PAREJO ${ }^{2}$

SUMMARY.-Melanin-based colorations in birds constitute a paradigm for the study of the molecular basis of phenotypic variation. Variation in the melanocortin-1 receptor $(M C R I)$ gene, a key regulator of melanin synthesis in feather melanocytes, can lead to changes in the production of melanin and hence in feather colour. Here we investigate the proximate mechanisms behind colour plumage polymorphism in the Eurasian Scops-owl Otus scops, a species showing pronounced variation in the degree of redness. Although eumelanin pigment was three times more abundant than pheomelanin pigments, the degree of plumage redness was more strongly associated with the amount of pheomelanin than eumelanin pigments. We detected only one synonymous substitution and one non-synonymous substitution in $M C 1 R$ which were, however, not associated with variation in plumage coloration. Redness variation in Eurasian Scops-Owls is primarily due to variation in pheomelanin, and to genes or regulatory elements other than MCR1 . - Avilés, J.M., Cruz-Miralles, A., Ducrest, A.-L., Simon, C., Roulin, A., Wakamatsu, K. \& Parejo, D. (2020). Redness variation in the Eurasian Scops-owl Otus scops is due to pheomelanin but is not associated with variation in the melanocortin-1 receptor gene (mclr). Ardeola, 67: 3-13.

Key words: eumelanin, MC1R, melanism, Otus scops, pheomelanin, polymorphism.

1 Departamento de Ecología Funcional y Evolutiva, EEZA-CSIC, Carretera de Sacramento s/n, 04120 La Cañada de San Urbano, Almería, Spain.

2 Departamento de Anatomía, Biología Celular y Zoología, Facultad de Ciencias, Universidad de Extremadura, Avenida de Elvas, s/n, 06006 Badajoz, Spain.

3 Department of Ecology and Evolution, University of Lausanne, Biophore Building, CH-1015 Lausanne, Switzerland.

4 Department of Chemistry, Fujita Health University School of Medical Sciences, Toyoake, Aichi 470-1192, Japan.

* Corresponding author: javiles@eeza.csic.es 
RESUMEN. - Las coloraciones basadas en melanina en las aves constituyen un paradigma para el estudio de las bases moleculares de la variación fenotípica. La variación en el gen del receptor de melanocortina-1 (MCRl), un regulador clave de la síntesis de melanina en los melanocitos de las plumas, puede provocar cambios en la producción de melanina y, por lo tanto, en el color de las plumas. Aquí investigamos los mecanismos próximos detrás del polimorfismo del plumaje de color en los autillos europeos Otus scops, una especie que muestra una marcada variación en el grado de rojismo. Aunque la cantidad de eumelanina era tres veces más abundante que la de feomelanina, el grado de rojismo del plumaje se asoció más fuertemente con la cantidad de feomelanina que con la eumelanina. Sólo detectamos una sustitución sinónima y una sustitución no sinónima en el MC1R que, sin embargo, no se asociaron con la variación en la coloración del plumaje. La variación de rojismo en el autillo europeo se debe principalmente a la variación en el contenido de feomelanina, y a genes o elementos reguladores de estos distintos del MCR1.-Avilés, J.M., Cruz-Miralles, A., Ducrest, A.-L., Simon, C., Roulin, A., Wakamatsu, K. y Parejo, D. (2020). La variación en el grado de rojismo en el autillo europeo Otus scops es debida a feomelaninas pero no se asocia con variación en el gen receptor de la melanocortina 1. Ardeola, 67: 3-13.

Palabras clave: eumelanina, feomelanina, MC1R, melanismo, Otus scops, polimorfismo.

\section{INTRODUCTION}

Understanding the molecular basis of phenotypic variation due to natural and sexual selection is a central goal of evolutionary biology and the study of melanin plumage colorations in birds has constituted a classic model system for its study (reviewed in Hubbard et al., 2010; Roulin and Ducrest, 2013). Melanin pigments serve a wide range of functions in birds, including physical or anti-parasite protection, and their variable deposition in feathers is responsible for most non-structural brown, black and grey colour plumage variation (McGraw et al., 2005; McGraw, 2006; Galván and Wakamatsu, 2016) useful for camouflage or signalling. Melanin consists of two main forms, eumelanin (hereafter EM, responsible for grey-black colorations) and pheomelanin (hereafter PM, determining reddish-brown colour variation) (McGraw, 2006), the ratio between these two pigments determining how plumage coloration is finally perceived (e.g. McGraw et al., 2005; Gasparini et al., 2009; Fargallo et al., 2018). The production of EM and PM is regulated by the activation of the melanocortin-1 receptor gene (MC1R hereafter) (Robbins et al., 1993). MC1R en- codes a seven-transmembrane domain Gprotein-coupled receptor expressed primarily in melanocytes of developing feathers (Mundy, 2005). High MC1R activity leads to high levels of production of EM, whereas low MCIR activity associates with increased production of red or yellow PM (Robbins et al., 1993). Studies on the genetic basic of pigmentation have shown that variability at the $M C 1 R$ locus can explain major dark/light colour polymorphism across a wide range of avian species (e.g. Theron et al., 2001; Mundy et al., 2004; Doucet et al., 2004; Uy et al., 2009; Gangoso et al., 2011), although there are a growing number of exceptions (e.g. MacDougall-Shackleton et al., 2003; Cheviron et al., 2006; Dobson et al., 2012; Derelle et al., 2013; Farrell et al., 2015; Abolins-Abols et al., 2018). The association between variation at the $M C 1 R$ and continuous melanin-based colour variations has received far less attention (see however Bourgeois et al., 2012; San-Jose et al., 2015; Corti et al., 2018).

The Eurasian Scops-owl Otus scops is a Strigiform species that is largely described as colour polymorphic, given the occurrence of two (dark-reddish and grey) main morphs (Del Hoyo et al., 1999; Galeotti et al., 2009). 
However, intermediate morphs are frequent (Galeotti et al., 2009; Parejo et al., 2018), and spectrophotometric analyses have shown that colour variation in Eurasian Scops-owls is continuous (Parejo et al., 2018). Recent findings from a wild population in southern Spain have revealed that the three morphs coexist within sex and age classes, and that the proportion of the three morphs is relatively stable, showing similar frequencies over eight studied years (Parejo et al., 2018). However, a temporal increase in the degree of redness of Italian Eurasian Scops-owls has been reported over the last century based on museum skin specimens (Galeotti et al., 2009). Although Eurasian Scops-owl colour variation is mostly defined by a graded change in body redness (Parejo et al., 2018), which resembles melanin-based redness variation in the polymorphic Tawny Owl Strix aluco (Gasparini et al., 2009), the absolute or relative role of EM and PM in determining plumage variation in Eurasian Scops-owls has not been investigated.

The main aim of this work was to study the proximate mechanisms behind colour variation in Eurasian Scops-owls. Firstly, we determined the role of melanin pigments in determining colour morph variation. Secondly, we sequenced $M C 1 R$ to examine whether single-nucleotide polymorphisms of this gene are associated with plumage colour morph variants.

\section{MATERIALS AND METHODS}

\section{Fieldwork}

The study was performed from 2010 to 2017 in the Hoya of Guadix-Baza, Granada, southeastern Spain $\left(37^{\circ} 18^{\prime} \mathrm{N}, 3^{\circ} 11^{\prime} \mathrm{W}\right)$. The area is an extensive agricultural landscape with scattered Holm Oaks Quercus ilex in which nest-boxes made of cork are located (see details in Rodríguez, Avilés, and Parejo,
2011; Parejo, Avilés, and Rodríguez, 2012; Parejo et al., 2018).

In the context of a long-term monitoring program of the Scops-owl population we routinely captured incubating females as well as males bringing food to the offspring (Parejo et al., 2018). In total 142 individuals were ringed with individually numbered metal rings and sexed by presence/absence of a brood patch. Captured adults were photographed for morph assignment. We extracted $225 \mathrm{ml}$ of blood from each bird by brachial venipuncture for genetic analyses, and plucked three to five feathers from the same part of the head for melanin determination.

\section{Colour scoring}

We took two standardised photos of each individual: one head-on, showing the head and breast plumage; and the other from behind, showing the back and wings. All photos were taken about $50 \mathrm{~cm}$ from the animal and always in shady areas around the nest, to homogenise light conditions. Photos were then used to score plumage coloration by focusing on the extent of redness on the head, breast and wings-back. Each body area was scored 1-3 according to whether they were predominantly greyer or browner (Parejo et al., 2018). We have previously shown that scores of the three body areas are highly correlated within individuals and that scores assigned by different observers to the same individual are highly repeatable (Parejo et al., 2018). Hence scores of the three body areas were summed to get an individual score for every bird (ranging from 3 to 9 ). Individuals were then classed as grey ( score $<5.5)$, intermediate $(5.5 \leq$ score $\geq 7$ ) or red-brown morph (score $>7$ ) (see Supplementary material, Appendix 1, Figure A1). Based on recapture of a subset of individuals of known age, we have previously shown 
that the morph score and morph classification are unaffected by age in Eurasian Scops-owls (Parejo et al., 2018). Hence, the possibility that age-related differences in plumage maturation might affect our results can be discarded.

\section{Melanin concentration in feathers}

We measured melanin composition and concentration in head feathers of 25 adult Eurasian Scops-owls. PM and EM concentration was estimated as described by Wakamatsu et al. (2002) and Ito et al. (2011). Feather samples (13-15mg) were homogenised with Ten-Broeck homogeniser at a concentration of $10 \mathrm{mg} / \mathrm{mL} \mathrm{H}_{2} \mathrm{O} .100 \mu \mathrm{L}$ (1 mg) aliquots were subjected to Soluene-350 solubilisation (Ozeki et al., 1996), alkaline hydrogen peroxide oxidation (Ito et al., 2011) and hydroiodic acid hydrolysis (Wakamatsu, Ito, and Rees, 2002). High-performance liquid chromatography (HPLC) was used to quantify EM and PM contents through specific degradation products, PTCA and TTCA for EM and PM by alkaline $\mathrm{H}_{2} \mathrm{O}_{2}$ oxidation of EM and PM, respectively, and 4-AHP by reductive hydrolysis of $\mathrm{PM}$ with hydriodic acid. EM content was estimated using a conversion factor of 25 for PTCA. For the conversion of TTCA in benzothiazole-type pheomelanin (BZ-PM) and 4-AHP in benzothiazine-type pheomelanin (BT-PM), we used factors of 36 and 7, respectively (Ito et al., 2011; d'Ischia et al., 2013).

\section{$M C 1 R$ genotyping}

Genomic DNA was extracted from blood using the DNeasy Tissue kit (Qiagen, Hombrechtikon, Switzerland) and the Biosprint robot 96 (Qiagen). A 921 bp fragment of the $M C 1 R$ gene was amplified using the following primers $M C 1 R \_4 \mathrm{Fw}$ (5'-GACCAT
GTCGACGCTGGC-3') and MC1R_955Rev (5'-GTCCCGCTGCCTACCAGGAG-3') designed on Barn Owl Tyto alba (San-Jose et al., 2015) and Tawny Owl (Emaresi et al., 2013) MC1R DNA sequences. The amplicon starts at $15 \mathrm{bp}$ downstream of the translation start site and stops 8 bp upstream of the stop codon; thus only 23 bp of the coding sequence are missing. PCRs were performed in $20 \mu \mathrm{L}$ containing $2.5 \mathrm{mM} \mathrm{MgCl} 2,0.2 \mathrm{mM}$ dNTPs, $4 \mu \mathrm{L}$ of GoTaq Reaction buffer $5 \times$, $4 \mu \mathrm{L}$ of Q solution (Qiagen, Hombrechtikon, Switzerland), 500nM of each primer and $0.1 \mathrm{U}$ of GoTaq DNA polymerase (Promega, Dübendorf, Schweiz) and 10ng of genomic DNA. The cycle conditions were the following: $95^{\circ} \mathrm{C}$ for $5 \mathrm{~min}$ followed by 35 cycles at $94^{\circ} \mathrm{C}$ for $30 \mathrm{~s}, 61^{\circ} \mathrm{C}$ for $30 \mathrm{~s}$ and $72^{\circ} \mathrm{C}$ for $60 \mathrm{~s}$ and then a final extension at $72^{\circ} \mathrm{C}$ for $10 \mathrm{~min}$. The amplicons of 142 individuals were then PCR purified and sequenced in both directions at Microsynth (Microsynth, Balgach, Switzerland). Sequences were analysed with CodonCode Aligner 8.02.

\section{Statistical Analysis}

Analyses were performed using SAS 9.4 software (SAS Institute Inc., Cary, NC).

Initially we ran a general linear model (GLM SAS procedure) to study whether pigment concentration depended on melanin type (i.e. EM versus PM which is the sum of BZ-PM and BT-PM) and adult sex as fixed terms. We also entered the interaction term between sex and melanin type to test whether the relative importance of EM versus PM pigments in explaining the degree of reddish coloration differed between the two sexes. Then we ran a multiple linear regression model to study the relationships between amounts of EM and total PM pigments as predictors of degree of redness. Standard model validation graphs (Zuur, 2009) revealed that model assumptions of homoge- 
neity of variance and normality of residuals were fulfilled. $\mathrm{P}$ values smaller than 0.05 were considered significant.

\section{Ethical note}

Data collection complies with the current laws of Spain and the fieldwork was authorised by the Consejería de Medio Ambiente y Ordenación del Territorio of the Junta de Andalucía (projects CGL2011-27561/BOS and CGL2014-56769-P; licence code: P06RNM-01862). The study protocol was reviewed and approved by the ethical committee of the CSIC.

\section{RESULTS}

\section{Melanin content in Eurasian Scops-owl feathers}

In all feathers we found both EM (mean \pm SE concentration $49.45 \pm 2.49 \mu \mathrm{g} / \mathrm{mg}$ ) and

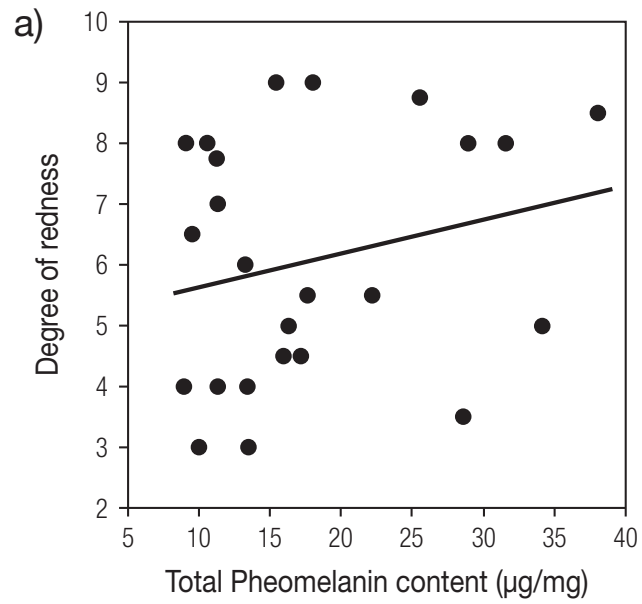

two types of PM: benzothiazine-type (BT$\mathrm{PM}$; mean \pm SE concentration $11.95 \pm 0.76$ $\mu \mathrm{g} / \mathrm{mg}$ ) and benzothiazole-type (BZ-PM; mean \pm SE concentration $4.53 \pm 0.42 \mu \mathrm{g} / \mathrm{mg}$ ) (Supplementary material, Appendix 1, Table A1, Figure A2). EM was more abundant than PM (melanin type effect: $F_{1,46}=151.56$, $P<0.0001$ ), and the pattern did not differ between male and female owls (sex*melanin type interaction: $F_{1,46}=0.0008, P=0.97$; sex effect: $F_{1,46}=0.83, P=0.35$ ).

EM was significantly and positively correlated with BZ-PM $\left(r_{\mathrm{p}}=0.46, P=0.021\right.$, $\mathrm{N}=25)$, but not with BT-PM $\left(r_{\mathrm{p}}=-0.05\right.$, $P=0.78, \mathrm{~N}=25)$ and the total amount of PM in feathers $\left(r_{\mathrm{p}}=0.34, P=0.09, \mathrm{~N}=25\right)$.

\section{Melanin content in relation to coloration}

The degree of redness was positively associated with the amount of PM but unrelated to the amount of EM in feathers (Multiple regression: $F_{2,21}=3.51, P=0.04 ; \mathrm{R}^{2}=0.25$; PM (Beta (SE): $0.53(0.201), t_{21}=2.64$,

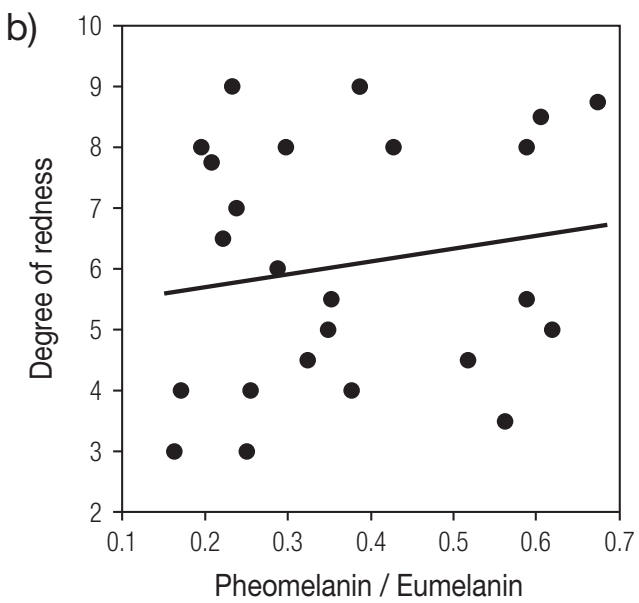

FIG. 1.-Relationships between degree of redness and a) PM content (i.e. BZ-PM + BT-PM) and b) PM / EM ratio in feathers of 25 Eurasian Scops-owls.

[Relaciones entre el grado de rojismo y a) el contenido de PM (i.e. BZ-PM + BT-PM) y b) la ratio PM / EM en plumas de 25 autillos.] 
$P=0.015 ;$ EM (Beta (SE): $-0.16(0.20)$, $\left.t_{21}=0.81, P=0.42\right)$. Correlation analyses also revealed that individuals with a greater degree of redness had a higher PM/EM ratio $\left(r_{\mathrm{p}}=0.41, P=0.04, \mathrm{~N}=25\right)$.

\section{$M C 1 R$ sequence and colour morphs}

Among the 142 adult owls there were only two variable sites at the $M C 1 R$ coding sequence: one synonymous substitution at site 111 (GAC codon mutated to GAT, encoded for the amino acid Aspartic acid, c.111C > T, D37D) and one non-synonymous amino acid substitution at site 70 (GCC codon mutated to ACC or even TCC, the encoded amino acids being either Alanine, Threonine or Serine, respectively, c.70G > A,T, A24T/S). Amino acid polymorphism at site 70 was shared by grey, intermediate and rufousbrown morphs (Supplementary material, Appendix 1, Table A2). The owls were monomorphic at all other sites known to determine major variation in melanin coloration in birds (Supplementary material, Appendix 1, Table A3).

\section{DISCUSSION}

\section{Melanin-based coloration in Eurasian Scops-owls}

Our results suggest that variation in redness in male and female Eurasian Scopsowls is due to variation in melanin content. The amount of EM pigment was three times greater than that of PM pigment in the owls' head feathers, a ratio similar to that reported for the orange-red breast plumage of Eastern Bluebirds Sialia sialis (McGraw, Safran, and Wakamatsu, 2005) or Barn Swallows Hirundo rustica (McGraw, Safran, and Wakamatsu 2005), but remarkably larger than that reported for other polymorphic owls such as the Tawny Owl (ratio EM/PM 1.08, Gasparini et al., 2009) or the Barn Owl (ratio EM/PM 0.13, Roulin et al., 2008).

Although EM pigments were more abundant in feathers than PM pigments, when we considered EM and PM concentration separately as predictors of colour variation, we found that reddishness was indicative of high PM pigment deposition, but that it was unrelated to EM pigment concentration in feathers. In addition, EM and PM were not significantly inter-correlated across feathers suggesting that major colour variation in redness in Eurasian Scops-owls is primarily due to variation in PM pigment deposition in feathers. These findings would add to previous studies on melanin pigment content in Tawny Owls (Gasparini et al., 2009) and Barn Owls (Roulin et al., 2013) showing that graded changes in reddishness are related to changes in PM deposition in feathers.

Why reddish coloration is correlated with the amount of PM pigments stored in feathers and not with EM pigments is intriguing, and may be due to a differential functional role of EM and PM. Melanins are known to increase the resistance of avian feathers to abrasion and wear (Bonser, 1995; Mackinven and Briskie, 2014), and although it is unknown whether EM or PM differ in their mechanical proprieties, PM-rich feathers are assumed weaker than EM-rich ones (e.g. Galván and Solano, 2016). Eurasian Scops-owls are secondary cavity nesters that perch in dense vegetation and hunt on the ground (Del Hoyo, Elliott, and Sargatal, 1999). Hence, feathers with a high amount of EM may have primarily evolved in Eurasian Scops-owls to resist abrasion.

Regarding PM, a growing body of evidence has provided support for the idea that PM-based plumage colorations may function as honest signals of quality of the bearer which are constrained by physiological trade-offs or social interactions (reviewed in Roulin, 2016; Arai et al., 2017; Galván, 
2018). PM production depends on the amount of cysteine and glutathione (GSH). GSH plays a critical role protecting cells from oxidative damages, in nutrient metabolism or in regulating immune function (Kosower and Kosower, 1978). Hence, there could be a physiological trade-off between anti-oxidative defence and PM expression, so that only high-quality individuals are able to express a high degree of reddishness (Galván et al., 2015). Indeed, it has been suggested that PM-based colour traits have a higher potential to evolve as honest signals of quality than EM-based colour traits due to the higher costs of PM production (Galván and Solano, 2016). In Eurasian Scops-owls, we have recently shown that two fitness surrogates (i.e. number of fledglings and the average fledgling mass at day 21) are not associated with female redness (Parejo et al., 2018), which would suggest that redness plumage variation would not reliably indicate differences in female quality. However, many aspects of individual quality (e.g. physiology) were not considered in that study. Moreover, the possible link between coloration and individual quality needs to be experimentally assessed in order to provide a sound test of a signalling function for PM coloration in Eurasian Scops-owls.

\section{$M C 1 R$ and colour variation in Eurasian Scops-owls}

We have found that variation in the coding sequence of the MC1R fails to explain variation in the degree of redness of plumage in Eurasian Scops-owls. Although we did not sequence a short (23 bp) portion of the entire $M C 1 R$ and cannot discard the possibility of a regulatory mutation near $M C 1 R$, we considered all SNP sites in this locus known to promote melanin colour variation (e.g. Theron et al., 2001; Gangoso et al., 2011; Mundy et al., 2004; Uy et al., 2009; Araguas et al., 2018). Hence, it seems unlikely that colour variation in Eurasian Scops-owls was determined by a non-synonymous mutation at the $M C 1 R$ locus. This result is not unexpected given that about 150 genes have been identified to be involved in coloration and/or pattern designs in animals (Hubbard et al., 2010), and that different genes could encode for EM and PM. Future studies on the genetic basis of the PM-based polymorphism of Eurasian Scops-owls should consider studying coloration in relation to variability in other genes involved in melanogenesis, such as MITF, ASIP, TYR, SLC45A2 and TYRP 1 that were not considered here (e.g. Chang et al., 2006; Gunnarsson et al., 2007; Linnen et al., 2009; Minvielle et al., 2010; Lehtonen et al., 2012; Bourgeois et al., 2016). In this regard, recent findings have shown that PM based polymorphism in the Reunion Grey White-eye Zosterops borbonicus was controlled by a single locus on chromosome 1 with two large-effect alleles (Bourgeois et al., 2017). In addition, other mechanisms, such as variation in expression of genes involved in melanogenesis and/or epigenetic effects at the MC1R locus, may better explain such continuous colour polymorphism (Emaresi et al., 2013; San-Jose et al., 2015; Galván, 2018). Finally, it is possible that differential regulation of a few genes rather than mutations in coding regions of the expressed genes could account for differences in coloration of Eurasian Scops-owls, such as recently shown in Darkeyed Juncos Junco hyemalis (Abolins-Abols et al., 2018).

Acknowledgements. - We thank Mónica Expósito-Granados for help during fieldwork, Yann Bourgeois and one anonymous referee for their constructive comments, and Borja Mila and Iñaki Balanzategui for help in feather photography. This work was funded by the Spanish Ministry of Economy and Competitiveness, projects CGL2008-00718, CGL2011-27561, CGL2014- 
56769-P and CGL2017-83503-P to JMA and DP. DP was supported by the regional government of Extremadura (TA13002) and $\mathrm{AC}$ by a $\mathrm{PhD}$ grant from the Spanish Ministry of Science (BES-2015074948) during the redaction of this manuscript.

Author CONTRIBUtions.-Jesús M. Avilés and Deseada Parejo conceived the study. Jesús M. Avilés, Ángel Cruz-Miralles and Deseada Parejo collected the data. Anne-Lyse Ducrest, Céline Simon and Alexandre Roulin performed the genetic analyses and Kazumasa Wakamatsu the pigments assessment of feathers. Jesús M. Avilés wrote a first draft of the manuscript and all authors contributed with comments.

\section{REFERENCES}

Abolins-Abols, M., Kornobis, E., Ribeca, P., Wakamatsu, K., Peterson, M.P., Ketterson, E.D. \& Mila, B. (2018). Differential gene regulation underlies variation in melanic plumage coloration in the dark-eyed junco (Junco hyemalis). Molecular Ecology, 27: 4501-4515.

Araguas, R.M., Sanz, N., Vinas, J. \& Vidal, O. (2018). MC1R polymorphism associated with plumage color variations in Coturnix chinensis. Animal Genetics, 49: 475-477.

Arai, E., Hasegawa, M., Makino, T., Hagino, A., Sakai, Y., Ohtsuki, H., Wakamatsu, K. \& Kawata, M. (2017). Physiological conditions and genetic controls of phaeomelanin pigmentation in nestling barn swallows. Behavioral Ecology, 28: 706-716.

Bonser, R.H.C. (1995). Melanin and the abrasion resistance of feathers. Condor, 97: 590-591.

Bourgeois, Y.X.C., Bertrand, J.A.M., Delahaie, B., Comuault, J., Duval, T., Mila, B.\& Thebaud, C. (2016). Candidate gene analysis suggests untapped genetic complexity in melanin-based pigmentation in birds. Journal of Heredity, 107: 327-335.

Bourgeois, Y.X.C., Bertrand, J.A.M., Thebaud, C. \& B. Mila. (2012). Investigating the role of the melanocortin-1 receptor gene in an extreme case of microgeographical variation in the pattern of melanin-based plumage pigmentation. Plos One, 7(12): e50906.
Bourgeois, Y.X.C., Delahaie, B., Gautier, M., Lhuillier, E., Male, P.J.G., Bertrand, J.A.M., Cornuault, J., Wakamatsu, K., Bouchez, O., Mould, C., Bruxaux, J., Holota, H., Mila, B. \& Thebaud, C. (2017). A novel locus on chromosome 1 underlies the evolution of a melanic plumage polymorphism in a wild songbird. Royal Society Open Science, 4: 14.

Chang, C.M., Coville, J.L., Coquerelle, G., Gourichon, D., Oulmouden, A. \& Tixier-Boichard, M. (2006). Complete association between a retroviral insertion in the tyrosinase gene and the recessive white mutation in chickens. Bmc Genomics, 7: 19.

Cheviron, Z.A., Hackett, S.J. \& Brumfield, T. (2006). Sequence variation in the coding region of the melanocortin-1 receptor gene (MC1R) is not associated with plumage variation in the blue-crowned manakin (Lepidothrix coronata). Proceedings of the Royal Society B-Biological Sciences, 273: 1613-1618.

Corti, M., Podofillini, S., Griggio, M., Gianfranceschi, L., Ducrest, A.L., Roulin, A., Cecere, J.G., Saino, N. \& Rubolini, D. (2018). Sequence variation in melanocortin-1-receptor and tyrosinase-related protein 1 genes and their relationship with melanin-based plumage trait expression in Lesser Kestrel (Falco naumanni) males. Journal of Ornithology, 159: 587-591. d'Ischia, M., Wakamatsu, K., Napolitano, A., Briganti, S., Garcia-Borron, J.C., Kovacs, D., Meredith, P., Pezzella, A., Picardo, M., Sarna, T., Simon, J.D. \& Ito, S. (2013). Melanins and melanogenesis: methods, standards, protocols. Pigment Cell \& Melanoma Research, 26: 616633.

Del Hoyo, J., Elliott, A. \& Sargatal, J. (1999). Handbook of the birds of the world, vol. 5: Barn owls to hummingbirds. Lynx edicions. Barcelona.

Derelle, R., Kondrashov, F.A., Arkhipov, V.Y., Corbel, H., Frantz, A., Gasparini, J., Jacquin, L., Jacob, G., Thibault, S. \& Baudry, E. (2013). Color differences among feral pigeons (Columba livia) are not attributable to sequence variation in the coding region of the melanocortin-1 receptor gene (MC1R). BMC research notes, 6: 310 .

Dobson, A.E., Schmidt, D.J. \& Hughes, J.M. (2012). sequence variation in the melano- 
cortin-1 receptor (MC1R) does not explain continent-wide plumage color differences in the australian magpie (Cracticus tibicen). Journal of Heredity, 103: 769-780.

Doucet, S.M., Shawkey, M.D., Rathburn, M.K., Mays, H.L. \& Montgomerie, R. (2004). Concordant evolution of plumage colour, feather microstructure and a melanocortin receptor gene between mainland and island populations of a fairy-wren. Proceedings of the Royal Society B-Biological Sciences, 271: 1663-1670.

Emaresi, G., Ducrest, A.L., Bize, P., Richter, H., Simon, C. \& Roulin, A. (2013). Pleiotropy in the melanocortin system: expression levels of this system are associated with melanogenesis and pigmentation in the tawny owl (Strix aluco). Molecular Ecology, 22: 4915-4930.

Fargallo, J.A., Martínez, F., Wakamatsu, K., Serrano, D. \& Blanco, G. (2018). Sex-dependent expression and fitness consequences of sunlight-derived color phenotypes. American Naturalist, 191: 726-743.

Farrell, L.L., Kupper, C., Burke, T. \& Lank, D.B. (2015). Major breeding plumage color differences of male ruffs (Philomachus pugnax) are not associated with coding sequence variation in the MC1R gene. Journal of Heredity, 106: 211-215.

Galeotti, P., Rubolini, D., Sacchi, R. \& Fasola, M. (2009). Global changes and animal phenotypic responses: melanin-based plumage redness of scops owls increased with temperature and rainfall during the last century. Biology Letters, 5: 532-534.

Galván, I. (2018). Predation risk determines pigmentation phenotype in nuthatches by melaninrelated gene expression effects. Journal of Evolutionary Biology, 31: 1760-1771.

Galván, I. \& Solano, F. (2016). Bird integumentary melanins: biosynthesis, forms, function and evolution. International Journal of Molecular Sciences, 17: 21.

Galván, I. \& Wakamatsu, K. (2016). Color measurement of the animal integument predicts the content of specific melanin forms. Rsc Advances, 6: 79135-79142.

Galván, I., Wakamatsu, K., Camarero, P.R., Mateo, R. \& Alonso-Álvarez, C. (2015). Lowquality birds do not display high-quality sig- nals: The cysteine-pheomelanin mechanism of honesty. Evolution, 69: 26-38.

Gangoso, L., Grande, J.M., Ducrest, A.L., Figuerola, J., Bortolotti, G.R., Andres, J.A. \& Roulin, A. (2011). MC1R-dependent, melanin-based colour polymorphism is associated with cellmediated response in the Eleonora's falcon. Journal of Evolutionary Biology, 24: 20552063.

Gasparini, J., Bize, P., Piault, R., Wakamatsu, K., Blount, J.D., Ducrest, A.L. \& Roulin, A (2009). Strength and cost of an induced immune response are associated with a heritable melanin-based colour trait in female tawny owls. Journal of Animal Ecology, 78: 608-616. Gunnarsson, U., Hellstrom, A.R., Tixier-Boichard, M., Minvielle, F., Bed'hom, B., Ito, S., Jensen, P., Rattink, A., Vereijken, A. \& Andersson, L. (2007). Mutations in SLC45A2 cause plumage color variation in chicken and Japanese quail. Genetics, 175: 867-877.

Hubbard, J.K., Uy, J.A.C., Hauber, M.E., Hoekstra, H.E. \& Safran, R.J. (2010). Vertebrate pigmentation: from underlying genes to adaptive function. Trends in Genetics, 26: 231-239.

Ito, S., Nakanishi, Y., Valenzuela, R.K., Brilliant, M.H., Kolbe, L. \& Wakamatsu, K. (2011). Usefulness of alkaline hydrogen peroxide oxidation to analyze eumelanin and pheomelanin in various tissue samples: application to chemical analysis of human hair melanins. Pigment Cell \& Melanoma Research, 24: 605-613.

Kosower, N.S. \& Kosower, E.M. (1978). The glutathione status of cells. International review of cytology, 54: 109-160.

Lehtonen, P.K., Laaksonen, T., Artemyev, A.V., Belskii, E., Berg, P.R., Both, C., Buggiotti, L., Bures, S., Burgess, M.D., Bushuev, A.V., Krams, I., Moreno, J., Magi, M., Nord, A., Potti, J., Ravussin, P.A., Sirkia, P.M., Saetre, G.P., Winkel, W. \& Primmer, C.R. (2012). Candidate genes for colour and vision exhibit signals of selection across the pied flycatcher (Ficedula hypoleuca) breeding range. Heredity, 108: 431-440.

Linnen, C.R., Kingsley, E.P., Jensen, J.D. \& Hoekstra, H.E. (2009). On the origin and spread of an adaptive allele in deer mice. Science, 325: 1095-1098. 
MacDougall-Shackleton, E.A., Blanchard, L. \& Gibbs, H.L. (2003). Unmelanized plumage patterns in old world leaf warblers do not correspond to sequence variation at the melanocortin-1 receptor locus (MC1R). Molecular Biology and Evolution, 20: 1675-1681.

Mackinven, K. \& Briskie, J.V. (2014). Differential wear of feathers in the polymorphic New Zealand Fantail (Rhipidura fuliginosa) - a selective advantage of melanism? Emu, 114: 154159.

McGraw, K.J., Safran, R.J. \& Wakamatsu, K. (2005). How feather colour reflects its melanin content. Functional Ecology, 19: 816-821.

McGraw, K.J. (2006). Mechanics of melaninbased coloration. In: Hill, G.E. \& McGraw, K.J. (eds). Bird coloration Vol. 1. Mechanisms and

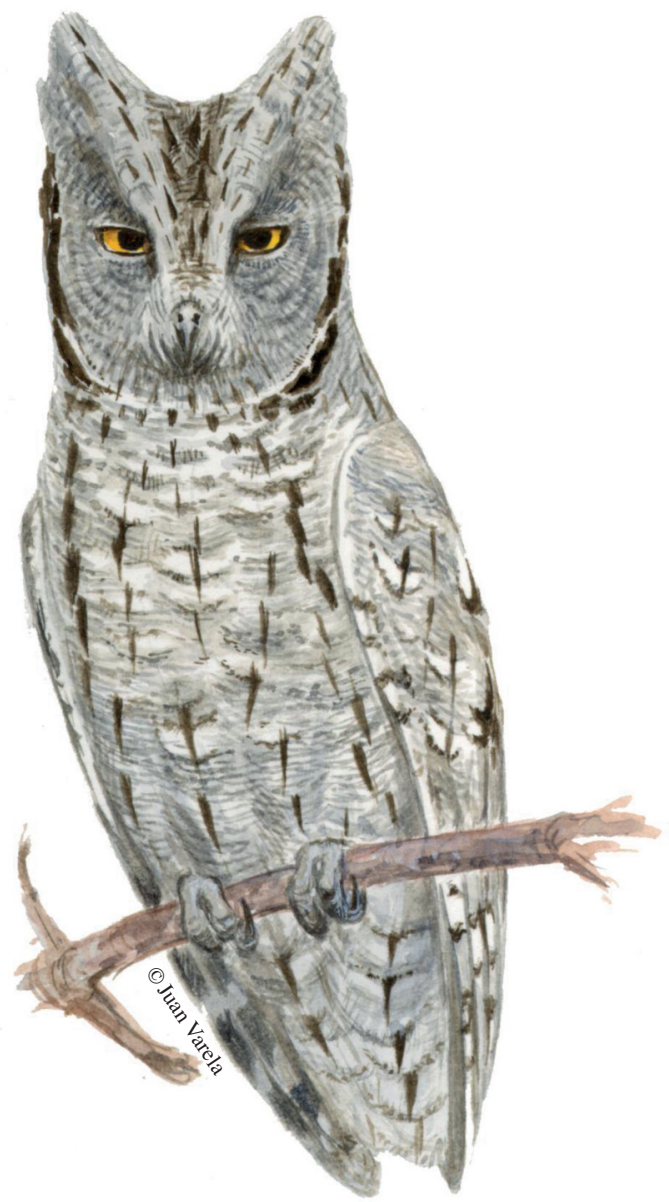

measurements, pp. 243-294. Harvard University Press. Cambridge.

Minvielle, F., Bed'hom, B., Coville, J.L., Ito, S., Inoue-Murayama, M. \& Gourichon, D. (2010). The "silver" Japanese quail and the MITF gene: causal mutation, associated traits and homology with the "blue" chicken plumage. Bmc Genetics, 11.

Mundy, N.I. (2005). A window on the genetics of evolution: MC1R and plumage colouration in birds. Proceedings of the Royal Society B-Biological Sciences, 272: 1633-1640.

Mundy, N.I., Badcock, N.S., Hart, T., Scribner, K., Janssen, K. \& Nadeau, N.J. (2004). Conserved genetic basis of a quantitative plumage trait involved in mate choice. Science, 303: 1870-1873.

Ozeki, H., Ito, S., Wakamatsu, K. \& Thody, A.J. (1996). Spectrophotometric characterization of eumelanin and pheomelanin in hair. Pigment Cell Research, 9: 265-270.

Parejo, D., Avilés, J.M. \& Rodríguez, J. (2012). Alarm calls modulate the spatial structure of a breeding owl community. Proceedings of the Royal Society B-Biological Sciences, 279: 21352141.

Parejo, D., Cruz-Miralles, A., Rodríguez-Ruiz, J., Expósito-Granados, M. \& Avilés, J.M. (2018). Determinants of color polymorphism in the Eurasian scops owl Otus scops. Journal of Avian Biology, in press.

Robbins, L.S., Nadeau, J.H., Johnson, K.R., Kelly, M.A., Rosellirehfuss, L., Baack, E., Mountjoy, K.G. \& Cone, R.D. (1993). Pigmentation phenotypes of variant extension locus alleles result from point mutations that alter $\mathrm{msh}$ receptor function. Cell, 72: 827-834.

Rodríguez, J., Avilés, J.M. \& Parejo, D. (2011). The value of nestboxes in the conservation of Eurasian Rollers Coracias garrulus in southern Spain. Ibis, 153: 735-745.

Roulin, A. (2016). Condition-dependence, pleiotropy and the handicap principle of sexual selection in melanin-based colouration. Biological Reviews, 91: 328-348.

Roulin, A., Almasi, B., Rossi-Pedruzzi, A., Ducrest, A.L., Wakamatsu, K., Miksik, I., Blount, J.D., Jenni-Eiermann, S. \& Jenni, L. (2008). Corticosterone mediates the condition-dependent 
component of melanin-based coloration. Animal Behaviour, 75: 1351-1358.

Roulin, A. \& Ducrest, A.L. (2013). Genetics of colouration in birds. Seminars in Cell \& Developmental Biology, 24: 594-608.

Roulin, A., Mangels, J., Wakamatsu, K. \& Bachmann, T. (2013). Sexually dimorphic melaninbased colour polymorphism, feather melanin content, and wing feather structure in the barn owl (Tyto alba). Biological Journal of the Linnean Society, 109: 562-573.

San-Jose, L.M., Ducrest, A.L., Ducret, V., Beziers, P., Simon, C., Wakamatsu, K. \& Roulin, A. (2015). Effect of the MC1R gene on sexual dimorphism in melanin-based colorations. $\mathrm{Mo}$ lecular Ecology, 24: 2794-2808.

Theron, E., Hawkins, K., Bermingham, E., Ricklefs, R.E. \& Mundy, N.I. (2001). The molecular basis of an avian plumage polymorphism in the wild: A melanocortin-1-receptor point mutation is perfectly associated with the melanic plumage morph of the bananaquit, Coereba flaveola. Current Biology, 11: 550557.

Uy, J.A.C., Moyle, R.G., Filardi, C.E. \& Cheviron, Z.A. (2009). Difference in plumage color used in species recognition between incipient species is linked to a single amino acid substitution in the melanocortin-1 receptor. American Naturalist, 174: 244-254.

Wakamatsu, K., Ito, S. \& Rees, J.L. (2002). The usefulness of 4-amino-3-hydroxyphenylalanine as a specific marker of pheomelanin. Pigment Cell Research, 15: 225-232.

Zuur, A.F. (2009). Mixed effects models and extensions in ecology with $R$. Springer.

\section{SupPlementary Electronic Material}

Additional supporting information may be found in the on-line version of this paper. See volume 67(1) in www.ardeola.org

Figure A1. Colour variation and pheomelanin content in Eurasian Scops-owls.

Figure A2. Light microscopy of Eurasian Scopsowl feathers.

Table A1. Raw melanin pigment content in feathers of 25 adult Eurasian Scops-owls.

Table A2. Colour morph score and $M C 1 R$ sequence variation for 137 adult Eurasian Scopsowls.

Table A3. MC1R sequence data for the 142 Eurasian Scops-owl individuals included in the study.

Submitted: July 12, 2019

Minor revision: September 02, 2019

Second version arrived: September 12, 2019

Accepted: September 18, 2019

Editor: Alice Cibois 